\title{
Chronic hepatitis B prognostic markers other than pre-treatment viral load predicted composite treatment outcome
}

\author{
Myo Nyein Aung ${ }^{1,3}$, Wattana Leowattana ${ }^{2}$, Khine Nwe Win ${ }^{2}$, Noppadon Tangpukdee ${ }^{2}$, \\ Sant Muangnoicharoen ${ }^{2}$ \\ ${ }^{1}$ Department of Public Health, Graduate School of Medicine, Juntendo University, Tokyo, Japan \\ ${ }^{2}$ Department of Clinical Tropical Medicine, Faculty of Tropical Medicine, Mahidol University, Thailand \\ ${ }^{3}$ Boromrajonani College of Nursing Nakhon Lampang (BCNLP), Lampang, Thailand
}

\begin{abstract}
Introduction: Chronic hepatitis B (CHB) is a globally common infectious disease. Its clinical course is complicated. In Southeast Asia, nucleos(t)ide analogues (NA) are commonly used drugs for CHB treatment. Composite treatment outcome has often been used in CHB clinical practice, but rarely predicted epidemiologically. This study aimed to compare the composite treatment outcome between CHB patients with low and high treatment-naïve viral load, and to identify its predictors

Methodology: This retrospective cohort study followed up 95 CHB patients on NA treatment for a year. Composite treatment outcome was defined as undetectable HBV DNA level, ALT normalization and, HBeAg clearance in the case of HBeAg-positive patients. Multinomial logistic regression analysis was applied to analyze the significant treatment response predictors.

Results: Complete composite treatment outcome was achieved by $52 \%$ of CHB patients with an initial viral load $<6.5 \mathrm{log} 10 \mathrm{copies} / \mathrm{ml}$, but $31 \%$ of those had an initial viral $\operatorname{load} \geq \log 6.5 \log { }_{10}$ copies $/ \mathrm{ml}$. Outcome was predicted by HBeAg negativity (adjusted relative risk ratio, $\mathrm{aRRR}=11.1,95 \%$ confidence interval, CI 3-41.3) and ALT normalization within the sixth month of therapy $(\mathrm{aRRR}=6.7, \mathrm{CI} 1.8-24.9)$. An elevation of ALT to more than 1.5 times the normal value $(40 \mathrm{IU} / \mathrm{ml})$ can lead to an incomplete response on NA therapy $(\mathrm{aRRR}=6.2$, CI 1.5-26.6.)

Conclusion: Routine clinical markers other than pre-treatment viral load predicted composite CHB outcome on NA Therapy.
\end{abstract}

Key words: chronic hepatitis B; predictors; treatment outcome

J Infect Dev Ctries 2013; 7(7):541-549. doi:10.3855/jidc.2759

(Received 25 May 2012 - Accepted 06 September 2012)

Copyright (C) 2013 Aung et al. This is an open-access article distributed under the Creative Commons Attribution License, which permits unrestricted use, distribution, and reproduction in any medium, provided the original work is properly cited.

\section{Introduction}

Hepatitis B is a common infection causing a global prevalence of 350 million chronic hepatitis B (CHB) cases [1,2]. An estimated 100 million hepatitis B carriers live in countries of the WHO-designated South-East Asia Region, where approximately 300,000 deaths are attributed to hepatitis B annually [3].

Southeast Asian countries, such as Thailand and Myanmar, have a high prevalence of chronic hepatitis $\mathrm{B}$ infection, with $5 \%$ to $7 \%$ of the adult population being long-term carriers or CHB patients $[2,4]$.

Compared to the natural evolution of $\mathrm{CHB}$ in western countries, the evolution of CHB presents some peculiarities in Asian countries where infection at childhood, and a resultant prolonged immune tolerance phase in infected persons, is common [5]. Unsuppressed, persistent viral replication contributes to a higher incidence of consequent hepatocellular carcinoma and CHB-related deaths [6,7].

There are two main options for anti-hepatitis B treatment: interferon therapy and nucleos $(\mathrm{t})$ ide analogue (NA) therapy $[8,9,10,11,12]$. The latter is preferred by clinicians because of its easy administration, minimal adverse effects, and the prevalence of the genotype $C$ virus in Asia $[10,13]$. The hepatitis B clinical course is complicated and the treatment outcome is difficult to predict $[14,15,16]$. Laboratory tests to monitor hepatitis B prognosis are costly and as yet are not covered by the health insurance system in many Asian developing countries [17]. It would be beneficial to determine the practically useful predictors of $\mathrm{CHB}$ treatment outcome for such settings.

The baseline HBV DNA level determines the longterm clinical outcome and CHB-related mortality [18]. 
It also influences the virological response to antivirals [19]. How treatment-naïve HBV DNA viral load level influences the one-year NA treatment outcome has yet to be studied in a Southeast Asia setting. We hypothesized that the CHB treatment outcome would be different, depending on the initial HBV DNA viral load of treatment-naïve patients. We therefore compared the composite hepatitis B treatment outcome between NA-treated patients with high and low pretreatment viral loads. Moreover, we aimed to determine the predictors of complete CHB treatment success after treating with NA therapy for one year.

\section{Methodology}

Study site

The study was conducted at the Hospital for Tropical Diseases, a tertiary care setting in Bangkok, Thailand.

\section{Ethic approval}

This study was approved by the ethics committee of the Faculty of Tropical Medicine, Mahidol University, Thailand (MUTM 2010-044-01). For the purposes of data collection, the director of the hospital permitted the review of the medical records of chronic hepatitis B patients attending and being treated at the Hospital for Tropical Diseases, Bangkok.

\section{Study population}

Eligible CHB patients were selected from 2005 to October 2010.

\section{Inclusion and exclusion criteria}

Patients who met the following criteria were included in the study:

1. Chronic hepatitis $\mathrm{B}(\mathrm{CHB})$ patients diagnosed HBsAg positive for more than six months or the presence of $\mathrm{HBsAg}$ and anti-HBc IgG in the serum or the presence of HBV DNA in the serum

2. Patients with HBV DNA level $\geq 5 \log { }_{10}$ copies $/ \mathrm{ml}$ or $20,000 \mathrm{IU} / \mathrm{ml}$ in $\mathrm{HBeAg}$-positive patients [11]

3. Patients with HBV DNA level $\geq 4 \log { }_{10}$ copies $/ \mathrm{ml}$ or $2,000 \mathrm{IU} / \mathrm{ml}$ in $\mathrm{HBeAg}$-negative patients [11]

4. Patients who had a serum alanine aminotransferase (ALT) level 1.5 times or higher than the upper limit of normal (ULN)

5. Treatment naïve $\mathrm{CHB}$ patients receiving nucleos $(t)$ ide analogues therapy for the first time

6. Men and women between 18 and 70 years of age
The following patients were excluded from the study:

1. Patients co-infected with the hepatitis $\mathrm{C}$ virus

2. CHB patients who already had hepatocellular carcinoma and acute liver failure before the treatment

3. Patients previously treated with interferon

4. Pregnant women

The study cohort was formed into two groups depending on whether the initial HBV DNA viral load level of the treatment-naïve patients was $<$ or $\geq 6.5 \mathrm{log}$ 10 copies $/ \mathrm{ml}$. A high initial viral load meant a pretreatment HBV DNA $\geq 6.5 \log { }_{10}$ copies $/ \mathrm{ml}$, and a low initial viral load meant $<6.5 \log { }_{10}$ copies $/ \mathrm{ml}$. The follow-up period was one year (12 months).

\section{Study outcome}

We defined the composite CHB treatment outcome as including all of the most interesting clinical elements:

1. Undetectable HBV DNA, indicating a successful and sustained suppression of HBV viral replication

2. ALT normalization, indicating minimal liver cell injury

3. HBeAg seroconversion, indicating immunological recovery and less viral replication $[8,9,10,11,12]$

Data management and recoding of treatment outcome

Complete treatment outcome was defined as an undetectable HBV DNA viral load, ALT normalization, and $\mathrm{HBeAg}$ negativity in the case of HBeAg-positive cases. Those cases who showed only an undetectable viral load were classified as "incomplete treatment outcome". Those who did not achieve the undetectable HBV DNA were classified as "lack of treatment outcome". Treatment outcome data was recorded in three categories as shown in Table 1.

\section{Laboratory tests and normal values}

In this study, two methods of assessing quantitative HBV DNA viral load measurement were used. The first was the COBAS Amplicor Monitor assay (Roche Diagnostics, Basel, Switzerland), with a detection range of $3 \times 10^{2}-2 \times 10^{5}$ copies per $\mathrm{ml}$ in the majority of the cases. The second was the Abbott Real Time HBV assay (Abbott Laboratories, Abbott Park, IL, USA), with a detection range of $10-110 \times 10^{6}$ $\mathrm{IU} / \mathrm{ml},(1 \mathrm{IU}=3.41$ copies $/ \mathrm{ml})$ in $28 \%$ of cases. The median value of minimal HBV DNA detection limit in this study was 317 copies/ml. Thus the undetectable 
Table 1. Study outcomes and categorization of treatment outcome data

\begin{tabular}{l|ccc}
\hline $\begin{array}{l}\text { Category of CHB treatment } \\
\text { outcome }\end{array}$ & $\begin{array}{l}\text { Lack of } \\
\text { treatment outcome }\end{array}$ & $\begin{array}{l}\text { Incomplete } \\
\text { treatment outcome }\end{array}$ & $\begin{array}{l}\text { Complete } \\
\text { treatment outcome }\end{array}$ \\
\hline HBeAg negative $\boldsymbol{C H B}$ & & & + \\
\hline Undetectable HBV DNA & - & + & + \\
ALT normalization & \pm & - & + \\
\hline HBeAg positive $\boldsymbol{C H B}$ & & + & + \\
\hline Undetectable HBV DNA & - & \pm & + \\
ALT normalization & \pm & \pm & + \\
HBeAg negativity & \pm & &
\end{tabular}

HBV DNA viral load in this study was taken to be an HBV DNA level < 317 copies $/ \mathrm{ml}$. This is an acceptable virological treatment outcome measurement according to current guidelines, and previous reports have indicated that patients achieving this level have been free of long-term complications $[9,18]$.

Serum alanine aminotransferase (ALT) level was assessed using a Cobas C501 analyzer (Roche Diagnostics, Basel, Switzerland), and HBsAg, HBeAg, anti $\mathrm{HBe}$ antibody and serum alpha fetoprotein (AFP) assays were conducted by using an Elecsys 2010 analyser (Roche Diagnostics, Basel, Switzerland) at the Hospital for Tropical Disease clinical laboratory.

ALT normalization was defined as an ALT level less than $40 \mathrm{IU} / \mathrm{ml}$. Disappearance of $\mathrm{HBeAg}$ after treatment was defined as $\mathrm{HBeAg}$ negativity.

\section{Statistical analysis}

Stata version 11 (StataCorp LP, College Station, TX, USA) was used to analyze the data. The continuous variables were summarized as mean and standard deviation (SD), or median and interquartile range (IQR) based on the distribution of data. Categorical data was summarized as percentages. At the 12-month follow up, the composite treatment outcome was compared between the two groups in the study. The non-parametric test of trend for the ranks of across ordered groups in Stata was used to compare the CHB treatment outcome, divided into three categories.

Predictor variables such as pre-treatment viral load, pretreatment ALT, $\mathrm{HBeAg}$ positivity, serum alpha fetoprotein, age, gender, and drugs used were analyzed using univariate multinomial regression, to determine the significant predictors of composite clinical outcomes.

A P-value less than 0.2 and clinical logic was used to discriminate the variables to be included in the final multivariate model. Crude Relative risk ratio (RRR) and adjusted relative risk ratio (aRRR) with a 95\% confidence interval (CI) were produced by multinomial regression analysis using Stata version 11. Significance was decided by a P-value less than 0.05 and a $95 \%$ confidence interval.

\section{Results}

This cohort study was comprised entirely of Thai patients. The average age of the patients was 44.5 years with male patients making up $72.63 \%$ of the cohort study. The average pretreatment HBV DNA viral load was $5.22(6.38-7.52) \log { }_{10}$ copies $/ \mathrm{ml} 1$ and the average ALT was $36(64-158) \mathrm{IU} / \mathrm{ml}$ (Table 2). All patients were naïve CHB commencing NA treatment. Almost half of the patients (41.05\%) received lamivudine.

We constructed the cohort based on whether the treatment-naïve HBV DNA viral load was $<$ or $\geq 6.5$ $\log _{10}$ copies $/ \mathrm{ml}$ (Table 2). Out of 95 patients, $47.37 \%$ had a HBV DNA viral load $\geq 6.5 \log 10$ copies $/ \mathrm{ml}$ before starting nucleos(t)ide analogue therapy. Table 3 shows the pretreatment characteristics of the two groups of patients. Age distribution, gender, and proportion of patients with high ALT (above 1.5 times ULN) were similar between the two groups; however, the proportion of $\mathrm{HBeAg-negative} \mathrm{CHB}$ was higher in the low initial viral load groups (Table 3). Other prognostic factors were well-balanced with no significant differences between the two groups. The 
Table 2. Baseline characteristic of chronic hepatitis B patients in the study

\begin{tabular}{l|c|c}
\hline & Number & Percentage \\
\hline Number & 95 & \\
Age years & $44.5( \pm 11.5)$ & \\
(mean, SD) & & 72.63 \\
Male Sex & 69 & 100 \\
Race & 95 & 43.16 \\
Thai & 41 & \\
HBeAg positive CHB & $64(36-158)$ & \\
ALT IU/ml & & \\
( median, IQR) & $6.38(5.22-7.52)$ & \\
HBV DNA viral load log copies/ml $_{\text {Median, IQR) }}$ & & \\
(Merum AFP ng /ml & $3.27(2.2-5.82)$ & 41.05 \\
(Median, IQR) & & 16.84 \\
Drugs used & 39 & 16.84 \\
Lamivudine & 16 & 22.11 \\
Adefovir & 16 & 3.16 \\
Entecavir & 21 & \\
Telbivudine & 3 & 15.79 \\
Lamivudine and Adefovir & & 32.63 \\
Alcohol & 15 & 51.58 \\
Current drinker & 31 & \\
Teetotaler & 49 & \\
Unknown & & \\
\hline Abbreviations: CHB, chronic hepatitis B; IQR, interquartile rage; ALT, serum alanine amino transferase; AFP, \\
serum alpha fetoprotein & & \\
\end{tabular}

Table 3. Clinical characteristic, prognostic factors and type of NA received by chronic hepatitis B patients in the groups formed by low and high pretreatment viral load

\begin{tabular}{|c|c|c|c|c|c|}
\hline \multirow[t]{2}{*}{ Pretreatment HBV DNA viral load } & \multicolumn{2}{|c|}{$\begin{array}{l}\geq \log _{10} 6.5 \\
\text { copies } / \mathrm{ml}\end{array}$} & \multicolumn{2}{|c|}{$\begin{array}{l}<\log _{10} 6.5 \\
\text { copies/ml }\end{array}$} & \multirow[t]{2}{*}{ P-value ${ }^{\#}$} \\
\hline & $\mathrm{n}$ & $\%$ & $\mathrm{n}$ & $\%$ & \\
\hline Number & 45 & 47.37 & 50 & 52.63 & \\
\hline \multicolumn{6}{|l|}{ Age } \\
\hline Age above 45 & 17 & 37.78 & 29 & 58.00 & 0.05 \\
\hline Age below 45 & 28 & 62.22 & 21 & 42.00 & \\
\hline \multicolumn{6}{|l|}{ Sex } \\
\hline Male & 32 & 71.11 & 37 & 74.00 & 0.75 \\
\hline Female & 13 & 28.89 & 13 & 26.00 & \\
\hline \multicolumn{6}{|l|}{ Pre treatment ALT } \\
\hline $\mathrm{ALT} \geq 1.5$ time $\mathrm{ULN}$ & 27 & 60.00 & 27 & 54.00 & 0.55 \\
\hline ALT $<1.5$ time ULN & 18 & 40.00 & 23 & 46.00 & \\
\hline \multicolumn{6}{|l|}{ Pre treatment $\mathrm{HBeAg}$ status } \\
\hline HBe Ag positive CHB & 26 & 57.78 & 15 & 30.00 & 0.01 \\
\hline HBeAg negative CHB & 19 & 42.22 & 35 & 70.00 & \\
\hline \multicolumn{6}{|l|}{ NA used } \\
\hline Lamivudine & 17 & 37.78 & 22 & 44.00 & \\
\hline Adefovir & 6 & 13.33 & 10 & 20.00 & \\
\hline Telbivudine & 12 & 26.67 & 9 & 18.00 & \\
\hline Entecavir & 8 & 17.78 & 8 & 16.00 & \\
\hline Lamividine + adefovir & 2 & 4.44 & 1 & 2.00 & 0.71 \\
\hline AFP above normal & 8 & 18.60 & 8 & 22.86 & 0.64 \\
\hline
\end{tabular}

Abbreviations: NA, nucleos(t)ide analogues; ALT, alanine aminotransferase;

AFP, alpha fetoprotein; ULN, upper limit of normal

Note: \# P-value for Chi square test. ALT normal value is $<40 \mathrm{IU} / \mathrm{ml}$ 
study cohort was followed up until 12 months of nucleos(t)ide analogue therapy.

Treatment outcome after one year of nucleos(t)ide analogues in patients with low $\left(<6.5 \log _{10}\right.$ copies $\left./ \mathrm{ml}\right)$ and high $\left(\geq 6.5 \log _{10}\right.$ copies $\left./ \mathrm{ml}\right)$ pretreatment viral load

After one year of NA treatment, the low initial viral load group obtained $52 \%$ complete treatment response, compared to only $31.11 \%$ in the high initial viral load group. In addition, $28 \%$ in the low initial viral load group did not achieve undetectable viral load, compared to $51.11 \%$ in the high initial viral load group (Figure). Thus the CHB treatment outcome was significantly different between the two groups (P for trend $=0.018)$ (Table 4).

Out of the total study population, $38.95 \%$ did not obtain undetectable HBV DNA level, while 18.95\% obtained undetectable HBV DNA but not complete treatment outcome (Table 4). Complete treatment outcome was obtained by $42.11 \%$ (40 out of 95 participants) (Table 4). Moreover, significantly better treatment outcome was observed in patients aged 45 years or older, $\mathrm{HBeAg}$-negative $\mathrm{CHB}$ patients, and those who obtained ALT normalization after six months of NA therapy.

CHB treatment response predictors by multivariate multinomial logistic regression

Univariate and multivariate multinomial logistic regression analyses were used to determine the significant prognostic indicators for successful CHB treatment outcome.

The final model (Table 5) included pre-treatment viral load, pre-treatment ALT, HBeAg positivity, age and gender.

Multivariate multinomial logistic regression analysis produced two significant predictors for complete treatment outcome: HBeAg-negative CHB (aRRR 11.13,CI 2.99-41.37) and ALT normalization in the sixth month of therapy (aRRR 6.67, CI 1.7924.87). These are significant predictors for a complete and successful CHB treatment outcome after one year of NA. In addition, a pre-treatment ALT level higher than 1.5 times ULN is significantly associated with an incomplete treatment response, aRRR 6.21, CI (1.4526.61).

\section{Discussion}

Uniqueness of the study

Hepatitis B clinical research is diverse, with different study outcomes being used as the single endpoint in many studies [20]. In this study, we used a clinically useful, realistic composite treatment outcome as the study endpoint measure. We monitored a cohort of $\mathrm{CHB}$ patients with low and high pretreatment viral loads to assess the one-year NA treatment outcome.

Current hepatitis B guidelines concurrently emphasize undetectable HBV DNA as the main

Figure. CHB treatment outcome after 12 months of NA
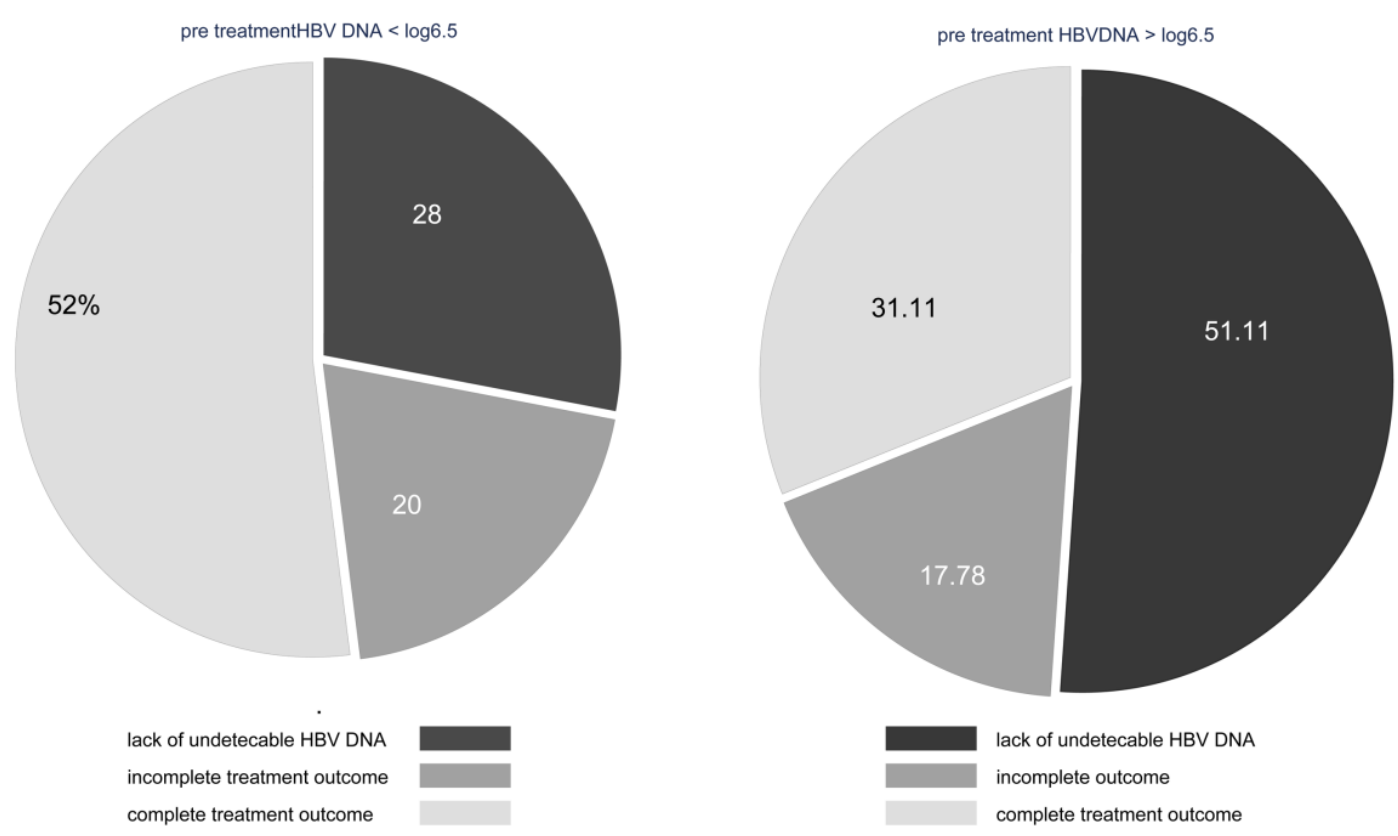
Table 4. Chronic hepatitis B treatment outcome after one year of NA treatment by different prognostic factors

\begin{tabular}{|c|c|c|c|c|c|c|c|}
\hline 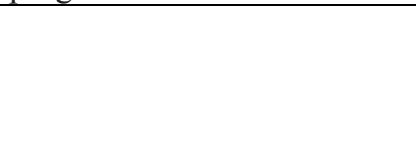 & \multicolumn{2}{|c|}{$\begin{array}{l}\text { Lack of } \\
\text { undetectable } \\
\text { HBV DNA } \\
\end{array}$} & \multicolumn{2}{|c|}{$\begin{array}{l}\text { Incomplete } \\
\text { treatment outcome }\end{array}$} & \multicolumn{2}{|c|}{$\begin{array}{l}\text { Complete } \\
\text { treatment } \\
\text { outcome }\end{array}$} & \multirow[t]{2}{*}{ P-value } \\
\hline & $n$ & $\%$ & $\mathbf{n}$ & $\%$ & 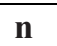 & $\%$ & \\
\hline $\mathrm{n}=95(100 \%)$ & 37 & 38.95 & 18 & 18.95 & 40 & 42.11 & \\
\hline Age group & & & & & & & 0.029 \\
\hline Age above 45 & 14 & 30.43 & 7 & 15.22 & 25 & 54.35 & \\
\hline Age below 45 & 23 & 46.94 & 11 & 22.45 & 15 & 30.61 & \\
\hline Sex & & & & & & & 0.331 \\
\hline Male & 25 & 36.23 & 13 & 18.84 & 31 & 44.93 & \\
\hline Female & 12 & 46.15 & 5 & 19.23 & 9 & 34.62 & \\
\hline $\begin{array}{l}\text { Treatment Naïve } \\
\text { HBV DNA }\end{array}$ & & & & & & & 0.018 \\
\hline HBV DNA $\geq \log 6.5$ & 23 & 51.11 & 8 & 17.78 & 14 & 31.11 & \\
\hline HBV DNA $<\log 6.5$ & 14 & 28.00 & 10 & 20.00 & 26 & 52.00 & \\
\hline Pre-treatment ALT & & & & & & & 0.468 \\
\hline Pre ALT $<1.5$ time ULN & 20 & 48.78 & 3 & 7.32 & 18 & 43.90 & \\
\hline Pre $A L T \geq 1.5$ time ULN & 17 & 31.48 & 15 & 27.78 & 22 & 40.74 & \\
\hline $\begin{array}{l}\text { Pre-treatment } \\
\text { HBeAg status }\end{array}$ & & & & & & & $<0.001$ \\
\hline $\mathrm{HBeAg}+\mathrm{CHB}$ & 26 & 63.41 & 8 & 19.51 & 7 & 17.07 & \\
\hline $\mathrm{HBeAg}-\mathrm{CHB}$ & 11 & 20.37 & 10 & 18.52 & 33 & 61.11 & \\
\hline $\begin{array}{l}\text { ALT normalization at sixth } \\
\text { month }\end{array}$ & & & & & & & 0.006 \\
\hline No & 16 & 51.61 & 8 & 25.81 & 7 & 22.58 & \\
\hline Yes & 18 & 30.00 & 9 & 15.00 & 33 & 55.00 & \\
\hline Drugs & & & & & & & 0.782 \\
\hline Lamivudine & 16 & 41.03 & 7 & 17.95 & 16 & 41.03 & \\
\hline Adefovir & 6 & 37.50 & 4 & 25.00 & 6 & 37.50 & \\
\hline Entecavir & 4 & 25.00 & 3 & 18.75 & 9 & 56.25 & \\
\hline Telbivudine & 11 & 52.38 & 4 & 19.05 & 6 & 28.57 & \\
\hline $\begin{array}{l}\text { Lamivudine and } \\
\text { Adefovir }\end{array}$ & 0 & 0.00 & 0 & 0.00 & 3 & 100.00 & \\
\hline
\end{tabular}

Abbreviations: NA, nucleos(t)ide analogues; HBV DNA, hepatitis virus DNA level viral load $\log _{10}$ copies /ml: ALT, alanine aminotransferase; AFP, alpha fetoprotein; ULN, upper limit of the normal

Note: ALT normal value is $<40 \mathrm{IU} / \mathrm{ml}$.

treatment outcome $[8,9,11,12]$, as it indicates the sustained elimination or suppression of HBV viral replication. In addition, surrogate outcomes, such as ALT normalization and $\mathrm{HBe} A g$ conversion in the case of $\mathrm{HBeAg}$-positive $\mathrm{CHB}$ patients, are of practical clinical interest. ALT normalization is a less specific marker for viral replication, but it is important when taking into account minimal liver cell damage and quality of the patient's life [9]. HBeAg clearance and $\mathrm{HBeAg}$ conversion are also meaningful turning points after starting treatment of $\mathrm{HBeAg}$-positive $\mathrm{CHB}$ patients [9,21]. Moreover, there have been reports of CHB-related complications despite the attainment of undetectable HBV DNA [14,22]. Therefore, it is preferable to interpret the HBV DNA viral load in the context of the ALT level and HBeAg status [20].

Better treatment outcome in low viral load and HBeAg negative hepatitis as predictors of composite outcome

The treatment outcome following a low pretreatment viral load was better than a high pretreatment viral load (Figure). The difference was 
Table 5. Clinical predictors of composite treatment outcomes in chronic hepatitis B after one year therapy of nucleos(t)ide analogues by multivariate multinomial logistic regression analysis

\begin{tabular}{|c|c|c|c|c|c|c|c|c|}
\hline \multirow{2}{*}{$\begin{array}{l}\text { Prognostic } \\
\text { factors } \\
n=95\end{array}$} & \multicolumn{4}{|c|}{$\begin{array}{l}\text { Undetectable viral load but incomplete treatment } \\
\text { outcome }\end{array}$} & \multicolumn{4}{|c|}{ Complete treatment outcome } \\
\hline & n $(\%)$ & $\begin{array}{l}\text { Crude RRR } \\
\text { (CI) }\end{array}$ & $\begin{array}{l}\text { aRRR } \\
(\mathrm{CI})\end{array}$ & $\mathrm{P}$ & n $(\%)$ & $\begin{array}{l}\text { Crude RRR } \\
\text { (CI) }\end{array}$ & $\begin{array}{l}\text { aRRR } \\
(\mathrm{CI})\end{array}$ & $\mathrm{P}$ \\
\hline Age $>45$ & $7(15.2)$ & $\begin{array}{l}1.05 \\
(0.33-3.33)\end{array}$ & $\begin{array}{l}0.90 \\
(0.23-3.5)\end{array}$ & 0.88 & $25(54.4)$ & $\begin{array}{l}2.74 \\
(\mathbf{1 . 1 0 - 6 . 8 9 )}\end{array}$ & $\begin{array}{l}1.2 \\
(0.36-4.19)\end{array}$ & 0.75 \\
\hline Male sex & $13(18.8)$ & $\begin{array}{l}1.25 \\
(0.36-4.31)\end{array}$ & $\begin{array}{l}1.04 \\
(0.25-4.25)\end{array}$ & 0.96 & $31(45.0)$ & $\begin{array}{l}1.65 \\
(0.60-4.55)\end{array}$ & $\begin{array}{l}1.8 \\
(0.50-6.43)\end{array}$ & 0.37 \\
\hline $\mathrm{Vl}(\mathrm{pre})<6.5 \log$ & $8(17.8)$ & $\begin{array}{l}2.1 \\
(0.7 .6 .4)\end{array}$ & $\begin{array}{l}1.37 \\
(0.38-4.91)\end{array}$ & 0.63 & $14(13.1)$ & $\begin{array}{l}3.1 \\
(1.2-7.70)\end{array}$ & $\begin{array}{l}1.27 \\
(0.39-4.16)\end{array}$ & 0.69 \\
\hline $\begin{array}{l}\text { ALT (pre) } \geq 1.5 \\
\text { times ULN }\end{array}$ & $15(27.8)$ & $\begin{array}{l}5.88 \\
(\mathbf{1 . 4 5 - 2 3 . 8 0 )}\end{array}$ & $\begin{array}{l}6.21 \\
(\mathbf{1 . 4 5 - 2 6 . 6 1 )}\end{array}$ & 0.01 & $22(40.7)$ & $\begin{array}{l}1.44 \\
(0.59-3.53)\end{array}$ & $\begin{array}{l}1.98 \\
(0.62-6.39)\end{array}$ & 0.25 \\
\hline $\begin{array}{l}\mathrm{HBeAg} \\
\text { negativity (pre) }\end{array}$ & $10(18.5)$ & $\begin{array}{l}2.95 \\
(0.92-9.49)\end{array}$ & $\begin{array}{l}2.25 \\
(0.56-9.05)\end{array}$ & 0.26 & $33(61.1)$ & $\begin{array}{l}11.14 \\
(\mathbf{3 . 7 9 - 3 2 . 7 5 )}\end{array}$ & $\begin{array}{l}11.13 \\
(\mathbf{2 . 9 9 - 4 1 . 3 7 )}\end{array}$ & $<0.001$ \\
\hline $\begin{array}{l}\text { ALT } \\
\text { normalization } \\
6 \text { month }\end{array}$ & $9(15.0)$ & $\begin{array}{l}1 \\
(0.31-3.21)\end{array}$ & $\begin{array}{l}1.41 \\
(0.37-5.33)\end{array}$ & 0.612 & $33(55.0)$ & $\begin{array}{l}4.19 \\
(\mathbf{1 . 4 6 - 1 2 . 0 7 )}\end{array}$ & $\begin{array}{l}6.67 \\
(\mathbf{1 . 7 9 - 2 4 . 8 7 )}\end{array}$ & 0.005 \\
\hline $\begin{array}{l}\text { Serum AFP (pre) } \\
\text { above normal }\end{array}$ & $2(11.11)$ & $\begin{array}{l}0.97 \\
(0.80-11.54)\end{array}$ & & $0.98^{*}$ & $6(15)$ & $\begin{array}{l}1.36 \\
(0.21-8.72)\end{array}$ & & $0.75^{*}$ \\
\hline
\end{tabular}

Abbreviation: N, number; Crude RRR,unadjusted relative risk ratio by univariate multinomial logistic regression; aRRR the relative risk ratio produced by adjusted multinomial logistic regression model; CI, 95\% confidence interval; VL (pre)= pre-treatment HBV DNA viral load level; HBeAg negativity $($ pre $)=\mathrm{HBeAg}$ negative $\mathrm{CHB}$ before treatment; ALT (pre)= pre-treatment ALT level; ALT = alanine aminotransferase, AFP, alpha fetoprotein; ULN, upper limit of the normal

Note: *P-value for AFT is that of univariate analysis. ALT normal value is $<40 \mathrm{IU} / \mathrm{ml}$.

significant both clinically and statistically. In the second part of our analysis by multivariate multinomial logistic regression, $\mathrm{HBeAg-negative}$ hepatitis was the significant predictor for complete treatment outcome (Table 5).

These clinical research findings are heralded by evidence from a recent viral kinetic study and metaanalysis of viral kinetic studies by Ribeiro and colleagues [23]. The viral clearance rate is significantly faster, and the viral half-life is shorter (13h vs.25 hr) for HBeAg-negative infection as compared to $\mathrm{HBeAg-positive} \mathrm{infection} \mathrm{[23].} \mathrm{In}$ addition, viral productivity is lower in most $\mathrm{HBeAg}$ negative hepatitis patients [24].

In the current cohort, assembled on the basis of the pretreatment viral load, $70 \%$ of the low pretreatment viral load patients were HBeAg negative (Table 3). The proportion of composite treatment outcome was shown to be higher among the low initial viral load group using trend analysis. After adjustment by all the covariant prognostic factors, $\mathrm{HBeAg-negative}$ hepatitis was shown to be the significant predictor of one-year NA response, aRRR11.13, CI (2.99-41.37) (Table 5). Therefore, these findings were synchronized with each other and supported by viral kinetic reports.
Pretreatment ALT 1.5 times higher than ULN as predictor for incomplete treatment outcome

The ALT level at presentation is of predictive value concerning long-term complications and mortality in the natural history of hepatitis B [25]. In the current study, we found that a pre-treatment ALT level higher than 1.5 times ULN is a significant predictor of incomplete treatment response in NAtreated patients (Table 4). Incomplete treatment outcome in this study refers to those patients who obtained an undetectable HBV DNA level without concomitant ALT normalization, or HBeAg conversion in the case of $\mathrm{HBeAg}$-positive CHB. Rising ALT or flare of ALT in a patient indicates a loss of tolerance in $\mathrm{HBeA}$-negative or flare in $\mathrm{HBeAg}$ positive CHB [26]. Such patients are likely to achieve undetectable HBV DNA but they might have a sustained ALT elevation or an ongoing immunological response. Similar findings in Telvibudine-treated $\mathrm{HBe}$ Ag-positive patients were reported by Guo-Cai and colleagues in China [27]. In our study, $22 \%$ of the patients received Telbivudine. 
Six-month ALT normalization predicts composite outcome after one year of $N A$

Assessment of ALT is an affordable laboratory test that can be monitored frequently in a resource-limited setting, and it is less costly than virological markers. Previous literature has pointed out the value of baseline ALT as a prognosis factor [28]. High ALT > $5 \mathrm{ULN}$ is predictive of a combined treatment response in interferon therapy [29]; however, evidence is not yet conclusive for NA therapy [29]. The immunological response and the presumptive phase of the disease is different between interferon candidate and NA candidate

ALT level changes are dynamic and fluctuating throughout the CHB course. ALT changes after starting treatment might be useful for clinical prognosis. We analysed whether a normalized ALT level at the sixth month would predict the composite outcome at one year of NA treatment. A significant association was revealed after adjustment by multivariate multinomial logistic regression (Table 5). Similarly, a previous study reported a significant correlation between ALT normalization at the six month and successful virological outcome at one year among the NA-treated, Thai, CHB patients infected with genotype $\mathrm{B}$ and $\mathrm{C}$ HBV viruses [30]. The current study result confirmed that ALT normalization at six months after commencing NA treatment significantly predicts undetectable HVB DNA and concomitant biochemical remission and immunological recovery (aRRR 6.67, CI 1.79-24.87). This would be a useful prediction guide for NA therapy treatment outcome in practice.

Overall, the one-year CHB treatment outcome on NA can be predicted by the pretreatment ALT level, the HBeAg status at the start of NA therapy, and ALT normalization at six months, while viral load influences the long-term clinical outcome.

\section{Conclusion}

Viral load suppression is an important CHB treatment outcome suggested by the guidelines but practically, a composite clinical outcome defines the quality of the patient's life. This investigation highlights the use of routine prognostic markers to predict the composite clinical treatment outcome in a developing setting where NA is widely used to treat CHB.

\section{Acknowledgements}

The article is dedicated to the Faculty of Tropical Medicine, Mahidol University, for its contribution to this study.
Professor Salvatore Rubino is acknowledged for persistant encouragement. Dr. Thaworn Lorga, Department of Research and Community Engagement, Boromrajonani College of Nursing Nakhon Lampang (BCNLP) is acknowledged for his support. Richard Lawrence Mann, Lampang Rajabhat University, Thailand, is acknowledged for refining the English.

\section{References}

1. Lavanchy D (2004) Hepatitis B virus epidemiology, disease burden, treatment, and current and emerging prevention and control measures. J Viral Hepat 11: 97-107.

2. Ott JJ, Stevens GA, Groeger J, Wiersma ST (2012) Global epidemiology of hepatitis B virus infection: New estimates of age-specific HBsAg seroprevalence and endemicity. Vaccine 30: 2212-2219.

3. (2011) Viral Hepatitis in the WHO South-East Asia Region. World Health Organization Regional Office for South-East Asia.

4. Custer B, Sullivan SD, Hazlet TK, Iloeje U, Veenstra DL, Kowdley KV (2004) Global Epidemiology of Hepatitis B Virus. Clin Gastroenterol 38: S158-S168.

5. Yim HJ, Lok AS (2006) Natural history of chronic hepatitis B virus infection: what we knew in 1981 and what we know in 2005. Hepatology 43: S173-181.

6. (2008) Hepatitis B.Fact sheet. World Health Organization..

7. Fattovich G, Bortolotti F, Donato F (2008) Natural history of chronic hepatitis B: Special emphasis on disease progression and prognostic factors. J Hepatol 48: 335-352.

8. European Association For The Study Of The L (2009) EASL Clinical Practice Guidelines: management of chronic hepatitis B. J Hepatol 50: 227-242.

9. Keeffe EB, Dieterich DT, Han S-HB, Jacobson IM, Martin P, Schiff ER, Tobias H (2008) A Treatment Algorithm for the Management of Chronic Hepatitis B Virus Infection in the United States: 2008 Update. Clin Gastroenterol Hepatol 6: 1315-1341.

10. Liaw Y-F (2009) Antiviral therapy of chronic hepatitis B: Opportunities and challenges in Asia. J Hepatol 51: 403-410.

11. Liaw Y-F, Leung N, Kao J-H, Piratvisuth T, Gane E, Han KH, Guan R, Lau GK, Locarnini S (2008) Asian-Pacific consensus statement on the management of chronic hepatitis B: a 2008 update. Hepatology International 2: 263-283

12. Lok ASF, McMahon BJ (2007) Corrections to AASLD guidelines on chronic hepatitis B. Hepatol 45: 1347.

13. Chainuvati S, Cheng J, Hou J, Hsu C, Jia J, Komolmit P, Kwon S, Lee C, Li H, Li Y, Liu C, Neo B, Peng C, Tanwandee T, Wongcharatrawee S, Wu J, Yu M, Zhang X (2009) Patterns of managing chronic hepatitis $\mathrm{B}$ treatment-related drug resistance: a survey of physicians in Mainland China, South Korea, Taiwan, and Thailand. Hepatol Int 3: 453-460.

14. Aung MN, Leowattana W, Tangpukdee N, Kittitrakul C (2011) Observation of genotype $\mathrm{C}$ infected chronic hepatitis $\mathrm{B}$ patients in clinical practice. J Infect Dev Ctries 5: 882-889.

15. Yim HJ, Lok AS-F (2006) Natural history of chronic hepatitis $B$ virus infection: What we knew in 1981 and what we know in 2005. Hepatology 43: S173-S181.

16. 16. McMahon BJ (2009) The natural history of chronic hepatitis B virus infection. Hepatol 49: S45-55. 
17. Mohamed R, Desmond P, Suh D-J, Amarapurkar D, Gane E, Guangbi YAO, Hou J-L, Jafri W, Lai CL, Lee C-H, Lee S-D, Lim SG, Guan R, Phiet PH, Piratvisuth T, Sollano J, Wu J-C (2004) Practical difficulties in the management of hepatitis B in the Asia-Pacific region. J Gastroenterol Hepatol 19: 958969.

18. Chen C-J, Yang H-I, Su J, Jen C-L, You S-L, Lu S-N, Huang G-T, Iloeje UH, for the REVEAL-HBV Study Group (2006) Risk of Hepatocellular Carcinoma Across a Biological Gradient of Serum Hepatitis B Virus DNA Level. JAMA 295: 65-73.

19. Sheng YJ, Liu JY, Tong SW, Hu HD, Zhang DZ, Hu P, Ren H (2011) Lamivudine plus adefovir combination therapy versus entecavir monotherapy for lamivudine-resistant chronic hepatitis B: a systematic review and meta-analysis. Virol J 8: 393.

20. Feld JJ, Wong DK, Heathcote EJ (2009) Endpoints of therapy in chronic hepatitis B. Hepatol 49: S96-S102.

21. Chien R-N, Yeh C-T, Tsai S-L, Chu C-M, Liaw Y-F (2003) Determinants for sustained $\mathrm{HBeAg}$ response to lamivudine therapy. Hepatol 38: 1267-1273.

22. Yuan HJ, Yuen MF, Ka-Ho Wong D, Sablon E, Lai CL (2005) The relationship between HBV-DNA levels and cirrhosis-related complications in Chinese with chronic hepatitis B. J Viral Hepat 12: 373-379.

23. Ribeiro RM, Germanidis G, Powers KA, Pellegrin B, Nikolaidis P, Perelson AS, Pawlotsky J-M (2010) Hepatitis B Virus Kinetics Under Antiviral Therapy Sheds Light on Differences in Hepatitis B e Antigen Positive and Negative Infections. Journal of Infectious Diseases 202: 1309-1318.

24. Volz T, Lutgehetmann M, Wachtler P, Jacob A, Quaas A, Murray JM, Dandri M, Petersen J (2007) Impaired Intrahepatic Hepatitis B Virus Productivity Contributes to Low Viremia in Most HBeAg-Negative Patients. Gastroenterol 133: 843-852.

25. Yuen MF, Yuan HJ, Wong DKH, Yuen JCH, Wong WM, Chan AOO, Wong BCY, Lai KC, Lai CL (2005) Prognostic determinants for chronic hepatitis B in Asians: therapeutic implications. Gut 54: 1610-1614.

26. Andreani T, Serfaty L, Mohand D, Dernaika S, Wendum D, Chazouillères O, Poupon R (2007) Chronic Hepatitis B Virus Carriers in the Immunotolerant Phase of Infection: Histologic Findings and Outcome. J Gastroenterol Hepatol 5: 636-641.

27. Lv G-C, Ma W-J, Ying L-J, Jin X, Zheng L, Yang Y-D (2010) Efficacy of telbivudine in HBeAg-positive chronic hepatitis B patients with high baseline ALT levels. World J Gastroenterol 16: 4095-4099.

28. van Nunen AB, Hansen BE, Suh DJ, Löhr HF, Chemello L, Fontaine H, Heathcote J, Song BC, Janssen HLA, de Man RA, Schalm SW (2003) Durability of HBeAg seroconversion following antiviral therapy for chronic hepatitis B: relation to type of therapy and pretreatment serum hepatitis B virus DNA and alanine aminotransferase. Gut 52: 420-424.

29. Kau A, Vermehren J, Sarrazin C (2008) Treatment predictors of a sustained virologic response in hepatitis B and C. J Hepatol 49: 634-651.

30. Aung MN, Leowattana W, Tangpukdee N, Kittitrakul C (2010) Nucleos(t)ide analogues treatment outcome in genotype B and C chronic hepatitis B. N Am J Med Sci 2: 365-370.

\section{Corresponding author}

Wattana Leowattana

Associate Professor

Faculty of Tropical Medicine

Mahidol University

420/6 Rajawithi Road, Ratchathewi

Bangkok 10400, Thailand

Telephone: 66 (0) 2354-9100-4, 66 (0) 2306-9100-9

Fax: 66 (0) 23549139

Email: tmwattana@mahidol.ac.th

Conflict of interests: No conflict of interests is declared. 